\title{
Analisis Faktor-Faktor yang Mempengaruhi Produk Domestik Regional Bruto Berdasarkan Kondisi Infrastruktur di Jawa Timur Menggunakan Regresi Data Panel \\ Studi Kasus di Jawa Timur
}

\author{
(Analysis Of Factors Affecting Gross Regional Domestic Product Based On Infrastructure \\ Conditions In East Java Using Panel Data Regression) \\ Rosa Viana Nur Addini ${ }^{*}$, Dwi Endah Kusrini² \\ ${ }^{1,2}$ Statistika Bisnis, Fakultas Vokasi, Institut Teknologi Sepuluh Nopember (ITS) \\ Kampus ITS Sukolilo-Surabaya 60111, Indonesia \\ E-mail: ${ }^{1 *}$ rosaviana98@gmail.com, ${ }^{2}$ dwi_endah@ statistika/its.ac.id
}

\begin{abstract}
ABSTRAK
Kinerja ekonomi yang kuat dikaitkan dengan infrastruktur yang ada di suatu negara atau wilayah. Infrastruktur merupakan aspek penting, mesin penggerak perekonomian dan penopang utama unsur-unsur sistem sosial ekonomi dalam masyarakat. Tujuan dari penelitian ini untuk mengetahui karakteristik data dan faktor-faktor mana saja yang mempengaruhi Produk Domestik Regional Bruto (PDRB) berdasarkan kondisi infrastruktur di Jawa Timur pada tahun 2016 hingga 2019 menggunakan statistika deskriptif dan regresi data panel. Hasil analisis terpilih model terbaik REM (Random Effect Model) dengan variabel infrastruktur kesehatan, infrastruktur air, dan infrastruktur hotel, penginapan, dan restoran dengan pengaruh positif signifikan terhadap PDRB Jawa Timur dengan koefisien determinasi sebesar 72,35\%, dimana model mampu menjelaskan variasi PDRB di Jawa Timur sebesar 72,35\%, sedangkan 27,65\% dijelaskan oleh variabel lain yang belum termasuk dalam model.
\end{abstract}

Kata kunci: Data Panel, Infrastruktur, PDRB, Regresi.

\section{ABSTRACT}

High economic achievement is related to the existing infrastructure in the country or region. Infrastructure is an important aspect as the driving force of the economy and the main supporter of the elements of the socio-economic system in society. The purpose of this study is to determine the characteristics of the data and what factors affect the Gross Regional Domestic Product (GRDP) at constant prices in 2010 based on infrastructure conditions in each Regency/City in East Java in 2016 to 2019 using descriptive statistics and data regression. panel. Based on the analysis, the best selected model is REM (Random Effect Model) with variables of health infrastructure, water infrastructure, and hotel, lodging, and restaurant infrastructure having a significant positive effect on East Java's GDP with a coefficient of determination of $72.35 \%$, where the model is able to explain GRDP variation in East Java is $72.35 \%$, while $27.65 \%$ is explained by other variables that have not been included in the model.

Keywords: Panel Data, Infrastructure, GRDP, Regression.

\section{PENDAHULUAN}

Keberhasilan untuk mengukur prestasi dan pembangunan ekonomi yang dilaksanakan suatu negara ataupun daerah dapat dapat dilihat dari Produk Domestik Regional Bruto (PDRB) di wilayah tersebut. Kebijakan dalam meningkatkan kegiatan perekonomian adalah dengan membangun sarana infrastruktur yang baik. Infrastruktur merupakan kebutuhan aktual yang mendasar dalam memberikan pelayanan kepada masyarakat sehingga ekonomi dan sosial daerah dapat berjalan dengan baik (Atmaja dan Mahalli, 2015). Provinsi Jawa Timur merupakan salah satu provinsi di Jawa yang memiliki nilai tambah barang dan jasa terbesar kedua di bawah Provinsi DKI Jakarta. Pada tahun 2019, Jawa Timur memiliki tambahan nilai atau share sebesar 14,63 persen dari PDB Indonesia (BPS Provinsi Jawa Timur, 2020). Industri Pengolahan, Perdagangan Besar dan Eceran, serta Pertanian, Kehutanan dan Perikanan merupakan penopang terbesar perekonomian Jawa Timur dengan komitmen tahun 2019 sebesar 60,12\% lebih tinggi dibandingkan tahun 2018 yang sebesar 59,82\%. Pendukung terbesar penyusunan PDRB Jawa Timur selanjutnya adalah pada bidang Kontruksi dan Penyediaan Akomodasi dan Makanan dan Minuman, masing-masing sebesar 9,36\% dan $5,92 \%$. Sementara itu, bidang usaha lain memberikan kontribusi di bawah $5 \%$, salah satunya di bidang transportasi sebesar 3,43\%; jasa pendidikan sebesar 2,64\%; jasa kesehatan sebesar $1,36 \%$ dan sektor penyediaan air bersih sebesar 0,09\% (BPS Provinsi Jawa Timur, 2020). Pemerintah Jawa Timur fokus pada 
infrastruktur proyek untuk menggarap perekonomian dan bantuan pemerintah daerah, salah satunya membuat jalan tol khususnya Tol Trans Jawa dan memberikan kerangka kualitas air bersih melalui pembangunan SPAM Regional Mojokerto-Lamongan (Sistem Penyediaan Air Minum) dan SPAM teritorial Umbulan (Bappeda Jawa Timur, 2018). Infrastruktur memiliki kontribusi sangat besar dalam memenuhi kebutuhan dasar dan mendukung kegiatan masyarakat sebagai penggerak perekonomian sekaligus pembangunan Kabupaten/Kota sehingga perlu mengetahui hubungan PDRB di Jawa Timur dengan variabel infrastruktur yang mempengaruhinya. Variabel infrastruktur yang digunakan yaitu infrastruktur air, pendidikan, kesehatan, jalan, hotel, penginapan dan restoran di Jawa Timur. Terpilihnya variabel infrastruktur tersebut karena pertimbangan mengenai ketersediaan data di publikasi BPS. Tujuan yang ingin dicapai dari penelitian ini untuk mengetahui karakteristik PDRB dan variabel infrastruktur serta mengetahui model regresi data panel apakah infrastruktur air, pendidikan, kesehatan, jalan, pariwisata memberikan pengaruh terhadap PDRB di Jawa Timur.

Penelitian ini menggunakan regresi data panel untuk mengetahui infrastruktur mana saja yang berpengaruh terhadap PDRB di Jawa Timur. Keuntungan dari regresi panel adalah menyediakan informasi banyak, lebih sedikit variabel umum, variabilitas besar dan heterogenitas unit individu yang diminati. Hal ini karena regresi panel memperhitungkan tidak hanya efek lateral, tetapi juga efek periode (Gujarati, 2004). Oleh sebab itu, regresi data panel digunakan untuk mengetahui variabel infrastruktur mana yang memiliki pengaruh signifikan terhadap PDRB di Jawa Timur.

\section{METODE}

\section{Regresi Data Panel}

Regresi data panel adalah model regresi untuk data terstruktur yang menggabungkan data cross-sectional dan data dari deret waktu. Berikut persamaan umum model regresi panel.

$$
Y_{i t}=\alpha_{i t}+\beta_{1} X_{1 i t}+\beta_{2} X_{2 i t}+\ldots+\beta_{k} X_{k i t}+\varepsilon_{i t}
$$

dimana:

$$
\begin{array}{ll}
Y_{i t} & =\text { variabel respon dari cross section ke-i dan time series ke-t. } \\
\alpha_{i t} & =\text { koefisien intersepsi dari cross section } \text { ke-i dan time series ke-t. } \\
\beta_{1}, \beta_{2}, \ldots, \beta_{k} & =\text { koefisien slope. } \\
X_{1 i t}, X_{2 i t}, \ldots, X_{k i t} & =\text { variabel prediktor dari cross section ke-i dan time series ke-t. } \\
\varepsilon_{i t} & =\text { error regresi dari cross section } \text { ke-i dan time series } \text { ke-t dengan IIDN }\left(0 ; \sigma^{2}\right) .
\end{array}
$$

\section{Estimasi Parameter Regresi Data Panel}

\section{A. Common Effect Model (CEM)}

CEM menggabungkan semua data tanpa memperdulikan individu dan waktu (Gujarati \& Porter, 2012).

Bentuk umum CEM sebagai berikut.

$$
Y_{i t}=\alpha+\beta_{1} X_{1 i t}+\beta_{2} X_{2 i t}+\ldots+\beta_{k} X_{k i t}+\varepsilon_{i t}
$$

dimana:

$$
\begin{array}{ll}
Y_{i t} & =\text { variabel respon dari unit cross section ke-i dan time series ke-t } \\
\alpha & =\text { koefisien intersep } \\
\beta_{1}, \beta_{2}, \ldots, \beta_{k} & =\text { koefisien slope } \\
X_{1 i t}, X_{2 i t}, \ldots, X_{k i t} & =\text { variabel prediktor dari cross section } \text { ke-i dan time series ke-t } \\
\varepsilon_{i} & =\text { residual cross section } \text { ke-i dan time series } \text { ke-t }
\end{array}
$$

\section{B. $\quad$ Fixed Effect Model (FEM)}

FEM mengasumsikan variasi nilai intersepsi dari unit individu atau periode waktu, namun slope koefisien yang tetap. Berikut model FEM yang digunakan pada penelitian ini.

a. FEM Antar Individu.

FEM antar individu mengasumsikan terdapat efek yang berbeda antar individu namun tidak terdapat efek waktu. Berikut model FEM antar individu.

$$
Y_{\mathrm{it}}=\alpha_{0}+\sum_{i=1}^{n-1} \alpha_{i} D_{i}+\beta_{1} X_{1 i t}+\beta_{2} X_{2 i t}+\ldots+\beta_{k} X_{k i t}+\varepsilon_{i t}
$$

b. FEM Antar Waktu. 
FEM antar waktu mengasumsikan terdapat efek yang berbeda antar waktu namun tidak terdapat efek individu. Berikut model FEM antar waktu (Widarjono, 2013).

$$
Y_{i t}=\lambda_{0}+\sum_{t=1}^{T-1} \lambda_{t} D_{t}+\beta_{1} X_{1 i t}+\beta_{2} X_{2 i t}+\ldots+\beta_{k} X_{k i t}+\varepsilon_{i t}
$$

\section{Random Effect Model (REM)}

Random Effect Model bertujuan untuk mengestimasi parameter model regresi menggunakan nilai galat dalam mengatasi permasalahan derajat bebas yang hilang dari model ketika menggunakan fixed effect model dan model dummy (Setiawan dan Kusrini 2010). Model REM secara umum sebagai berikut.

$$
Y_{i t}=\bar{\beta}_{0}+\beta_{1} X_{1 i t}+\beta_{2} X_{2 i t}+\ldots+\beta_{k} X_{k i t}+v_{i t}
$$

dimana $v_{i t}=u_{i}+\varepsilon_{i t}$ dengan $\mu_{i}$ adalah komponen error dari data cross section dan $\varepsilon_{i t}$ merupakan kombinasi komponen error cross section dan time series (Hsiao, 2003).

\section{Pemilihan Model Regresi Data Panel}

\section{A. Uji Chow}

Uji Chow yang digunakan untuk menguji apakah diantara model CEM atau model FEM yang terpilih untuk mengestimasi data panel (Greene, 2003). Berikut hipotesis uji chow.

$\mathrm{H}_{0}: \alpha_{1}=\alpha_{2}=\ldots=\alpha_{n}=0$

$\mathrm{H}_{1}$ : minimal ada satu $\alpha_{i} \neq 0$ yang berbeda

Statistik uji:

$$
F=\frac{\left(R_{L S D V}^{2}-R_{\text {pooled }}^{2}\right) /(n-1)}{\left(1-R_{L S D V}^{2}\right) /(n T-n-K)}
$$

dimana:

$R_{L S D V}^{2} \quad:$ R-square untuk FEM

$R_{\text {pooled }}^{2} \quad:$ R-square untuk CEM

n : jumlah pada cross section

$\mathrm{T} \quad$ : jumlah pada time series

$\mathrm{K} \quad$ : jumlah variabel prediktor.

Daerah kritis : tolak $\mathrm{H}_{0}$ apabila $\mathrm{F}>\mathrm{F}_{\alpha(\mathrm{n}-1, \mathrm{nT}-\mathrm{n}-\mathrm{K})}$ artinya $\mathrm{FEM}$ sebagai model terpilih.

\section{B. Uji Hausman}

Uji Hausman yang digunakan untuk menguji apakah diantara model REM atau model FEM yang terpilih untuk mengestimasi data panel. Berikut hipotesis uji hausman.

Hipotesis:

$\mathrm{H}_{0}: \operatorname{corr}\left(\mathrm{X}_{\mathrm{it}}, \mathrm{e}_{\mathrm{it}}\right)=0$

$\mathrm{H}_{1}: \operatorname{corr}\left(\mathrm{X}_{\mathrm{it}}, \mathrm{e}_{\mathrm{it}}\right) \neq 0$

Statistik uji:

$$
W=\mathbf{A}^{\prime}\left[\operatorname{var}\left(\hat{\beta}_{F E M}\right)-\operatorname{var}\left(\hat{\beta}_{R E M}\right)\right]^{-1} \mathbf{A}
$$

dengan $\mathbf{A}=\left(\hat{\beta}_{F E M}\right)-\left(\hat{\beta}_{R E M}\right)$

dimana:

$\hat{\beta}_{F E M}=$ estimasi parameter model fixed effect

$\hat{\beta}_{R E M}=$ estimasi parameter model random effect

Daerah kritis: tolak $\mathrm{H}_{0}$ jika $W>\chi_{\alpha ; k}^{2}$ (Greene, 2006).

\section{Uji Lagrange Multiplier}

Uji Lagrange Multiplier (LM) digunakan untuk menguji apakah diantara model REM atau model CEM yang terpilih untuk mengestimasi data panel uji (Widarjono, 2017). Berikut hipotesis dari pengujian LM.

$\mathrm{H}_{0}: \sigma_{\mathrm{i}}^{2}=0$

$\mathrm{H}_{1}: \sigma_{\mathrm{i}}^{2} \neq 0$

Statistik uji : 


$$
L M=\frac{n T}{2(T-1)}\left[\frac{\sum_{i=1}^{n}\left(T \hat{e}_{i t}\right)^{2}}{\sum_{i=1}^{n} \sum_{t=1}^{T} \hat{e}^{2}{ }_{i t}}-1\right]^{2} .
$$

dengan $\hat{e}_{i t}=Y_{i t}-\hat{Y}_{i t}$

dimana:

$\mathrm{n} \quad=$ Jumlah cross section

$\mathrm{T}=$ Jumlah time series

$\hat{e}_{i t}=$ Residual dari metode OLS (model common effect)

Daerah kritis : tolak $\mathrm{H}_{0} \mathrm{jika} \mathrm{LM}>\chi_{(K, \alpha)}^{2}$ (Greene, 2003).

\section{Produk Domestik Regional Bruto (PDRB)}

Produk Domestik Regional Bruto (PDRB) merupakan indikator untuk menentukan kondisi perekonomian di suatu daerah dalam periode tertentu yang bertujuan untuk membuat kebijakan daerah, memberikan informasi dengan menggambakan kinerja perekonomian daerah setempat, dan mengevaluasi hasil pembangunan (BPS Provinsi Jawa Timur, 2020).

\section{Infrastruktur}

Infrastruktur merupakan sarana prasarana yang dibuat atau dibutuhkan oleh organisasi publik maupun pemerintah sebagai fasilitas fisik dalam transportasi, tenaga listrik, pembuangan limbah, penyediaan air dan administrasi lain untuk memberikan fasilitas yang berkaitan dengan kepentingan ekonomi dan sosial. (Kodoatie, 2003).

\section{Data dan Sumber Data}

Data pada penelitian ini menggunakan data sekunder yang diperoleh dari publikasi BPS Provinsi Jawa Timur yaitu Jawa Timur Dalam Angka dan Kabupaten/Kota di Jawa Timur Dalam Angka yang diterbitkan tahun 2016 hingga 2019 mengenai infrastruktur dan PDRB atas dasar harga konstan 2010 Kabupaten/Kota di Jawa Timur tahun 2016 hingga 2019.

\section{Identifikasi Variabel}

Penelitian ini menggunakan variabel penelitian sebagai berikut.

Tabel 1. Variabel Penelitian

\begin{tabular}{|c|c|c|c|}
\hline Variabel & Keterangan & Satuan & Definisi Operasional \\
\hline$Y_{\text {it }}$ & PDRB & Miliar & - \\
\hline $\mathrm{X}_{1 \mathrm{it}}$ & $\begin{array}{l}\text { Infrastruktur } \\
\text { Kesehatan }\end{array}$ & Unit & $\begin{array}{c}\text { Jumlah Rumah Sakit, Puskesmas, Posyandu, dan Polindes (BPS Provinsi } \\
\text { Jawa Timur, 2020). }\end{array}$ \\
\hline $\mathrm{X}_{2 \mathrm{it}}$ & $\begin{array}{l}\text { Infrastruktur } \\
\text { Pendidikan }\end{array}$ & Unit & $\begin{array}{l}\text { Jumlah gedung SD/MI, SMP/MTs, SMA/SMK/MA (Rokhmat et al., } \\
\text { 2020). }\end{array}$ \\
\hline $\mathrm{X}_{3 \mathrm{it}}$ & Infrastruktur Air & $\mathrm{m}^{3}$ & $\begin{array}{c}\text { Banyaknya air bersih dari perusahaan air bersih yang disalurkan kepada } \\
\text { pelanggan (BPS Provinsi Jawa Timur, 2020). }\end{array}$ \\
\hline $\mathrm{X}_{4 \mathrm{it}}$ & $\begin{array}{l}\text { Infrastruktur Hotel, } \\
\text { Penginapan, dan } \\
\text { Restoran }\end{array}$ & Unit & $\begin{array}{l}\text { Jumlah hotel dan penginapan di Provinsi Jawa Timur (Rokhmat et al., } \\
\text { 2020) }\end{array}$ \\
\hline $\mathrm{X}_{5 \mathrm{it}}$ & Infrastruktur Jalan & $\mathrm{Km}$ & Panjang Jalan Provinsi Jawa Timur (BPS Provinsi Jawa Timur, 2020) \\
\hline
\end{tabular}

\section{Langkah Analisis}

Langkah analisis yang digunakan pada faktor-faktor yang berpengaruh terhadap Produk Domestik Regional Bruto (PDRB) dengan langkah analisis sebagai berikut.

1. Melakukan karakteristik data

2. Melakukan analisis regresi data panel.

3. Melakukan pemilihan estimasi model regresi data panel.

4. Melakukan uji signifikansi parameter. 
5. Melakukan uji asumsi multikolinearitas.

6. Melakukan pengujian asumsi residual Identik, Independen, dan Berdistribusi Normal (IIDN).

7. Melakukan interpretasi model.

8. Membuat kesimpulan dan saran.

\section{HASIL DAN PEMBAHASAN}

\section{Karakteristik PDRB dan Infrastruktur}

Karakteristik PDRB dan infrastruktur-infrastruktur di Jawa Timur tahun 2016 sampai 2019 di Kabupaten/Kota Jawa Timur disajikan dalam Tabel 2.

Tabel 2. Karakteristik PDRB dan Infrastruktur

\begin{tabular}{ccccc}
\hline Variabel & Rata-rata & Minimum & Medium & Maksimum \\
\hline Y & 40690,01 & 4079 & 21496 & 410970 \\
X1 & 1384,704 & 173 & 1398 & 3291 \\
X2 & 1061,671 & 112 & 1070,5 & 2364 \\
X3 & 16577358 & 198800 & 4883474 & 363252433 \\
X4 & 191,3026 & 17 & 63 & 1616 \\
X5 & 1094,021 & 97,013 & 1001,22 & 2996,27 \\
\hline
\end{tabular}

Tabel 2 menunjukkan rata-rata PDRB atas harga konstan 2010 (Y) di Jawa Timur selama kurun waktu 2016 sampai 2019 sebesar Rp40690,01 miliar dan angka PDRB atas harga konstan 2010 (Y) yang paling besar berada di Kota Surabaya pada tahun 2019 sebesar Rp410970 miliar sedangkan yang paling rendah berada di Kota Blitar pada tahun 2016 sebesar Rp4079 miliar. Nilai tengah PDRB atas harga konstan 2010 (Y) sebesar 21496 yang artinya 50\% berada di atas Rp 21496 miliar dan 50\% lainnya berada di bawah Rp21496 miliar.

Rata-rata infrastruktur kesehatan (X1) di Jawa Timur selama kurun waktu 2016 sampai 2019 sebesar 1384,704 atau 1385 unit dan infrastruktur kesehatan (X1) yang paling banyak berada di Kabupaten Malang pada tahun 2016 sebanyak 3291 unit sedangkan yang paling sedikit berada di Kota Blitar pada tahun 2016 sebanyak 173 unit. Nilai tengah infrastruktur kesehatan (X1) sebesar 1398 yang artinya 50\% berada di atas 1398 unit dan 50\% lainnya berada di bawah 1398 unit.

Rata-rata infrastruktur pendidikan (X2) di Jawa Timur selama kurun waktu 2016 sampai 2019 sebesar 1061,671 atau 1062 unit dan infrastruktur pendidikan (X2) yang paling banyak berada di Kabupaten Jember pada tahun 2019 sebanyak 2364 sekolah sedangkan yang paling sedikit berada di Kota Mojokerto pada tahun 2016, 2017 dan 2019 sebanyak 112 sekolah. Nilai tengah infrastruktur pendidikan (X2) sebesar 1070,5 yang artinya 50\% berada di atas 1070,5 unit dan 50\% lainnya berada di bawah 1070,5 unit.

Rata-rata infrastruktur air (X3) di Jawa Timur selama kurun waktu 2016 sampai 2019 sebesar 16577358 $\mathrm{m}^{3}$ dan penyaluran air bersih yang paling besar berada di Kota Surabaya pada tahun 2019 sebesar 363.252.433 $\mathrm{m}^{3}$ sedangkan yang paling rendah berada di Kota Batu pada tahun 2017 sebesar $198.800 \mathrm{~m}^{3}$. Nilai tengah infrastruktur air (X3) sebesar 4.883.474 yang artinya 50\% berada di atas $4.883 .474 \mathrm{~m}^{3}$ dan $50 \%$ lainnya berada di bawah $4.883 .474 \mathrm{~m}^{3}$.

Rata-rata infrastruktur hotel, penginapan dan restoran (X4) di Jawa Timur selama kurun waktu 2016 sampai 2019 sebesar 191,3026 atau 191 unit dan infrastruktur hotel, penginapan dan restoran yang paling banyak berada di Kota Surabaya pada tahun 2019 sebanyak 1.616 unit sedangkan yang paling sedikit berada di Kabupaten Sampang pada tahun 2016, 2018 dan 2019 sebanyak 17 unit. Nilai tengah sebesar 63 yang artinya $50 \%$ berada di atas 63 unit dan 50\% lainnya berada di bawah 63 unit.

Rata-rata infrastruktur jalan (X5) di Jawa Timur selama kurun waktu 2016 sampai 2019 sebesar 1094,021 $\mathrm{km}$ dan infrastruktur jalan (X5) yang paling panjang selama kurun waktu 2016 sampai 2019 berada di Kabupaten Banyuwangi pada tahun 2016 sebesar 2996,27 km sedangkan yang paling pendek berada di Kota Pasuruan pada tahun 2018 sebesar 97,013 km. Nilai tengah infrastruktur jalan (X5) sebesar 1001,22 yang artinya $50 \%$ berada di atas $1001,22 \mathrm{~km}$ dan $50 \%$ lainnya berada di bawah 1001,22 km.

\section{Model Estimasi Regresi Data Panel}

\section{A. CEM}

Model CEM pada PDRB dan faktor-faktor yang mempengaruhinya berdasarkan Kabupaten/Kota di Jawa Timur pada tahun 2016-2019 adalah sebagai berikut.

$\hat{Y}_{i t}=2821,403+27,914 X_{1}-15,087 X_{2}+0,00088 X_{3}+20,927 X_{4}-3,0005 X_{5}$ 
Nilai koefisien determinasi pada model CEM sebesar 0,8762, artinya model mampu menjelaskan variasi PDRB di Jawa Timur sebesar 87,62\%, sedangkan 12,38\% lainnya dijelaskan oleh variabel lain yang belum masuk dalam model.

\section{B. FEM}

a. FEM Antar Individu

Berikut model FEM bervariasi antar individu pada PDRB Jawa Timur.

$\hat{Y}_{i t}=131612,6+\sum_{i=1}^{37} \alpha_{i} D_{i}+3,788 X_{1}-5,647 X_{2}+0,001 X_{3}+16,166 X_{4}-1,106 X_{5}$

Nilai koefisien determinasi pada model FEM antar individu sebesar 0,9977, artinya model mampu menjelaskan variasi PDRB di Jawa Timur sebesar 99,77\%, sedangkan 0,23\% lainnya dijelaskan oleh variabel lain yang belum masuk dalam model.

b. FEM Antar Waktu

Berikut model FEM bervariasi antar waktu pada PDRB Jawa Timur.

$\hat{Y}_{i t}=1089,915+\sum_{t=1}^{3} \lambda_{t} D_{t}+27,819 X_{1}-15,204 X_{2}+0,001 X_{3}+20,493 X_{4}-2,759 X_{5}$

Nilai koefisien determinasi pada model FEM antar waktu sebesar 0,8766, artinya model mampu menjelaskan variasi PDRB di Jawa Timur sebesar 87,66\%, sedangkan 12,34\% lainnya dijelaskan oleh variabel lain yang belum masuk dalam model.

Dilihat nilai koefisien determinasi $\left(\mathrm{R}^{2}\right)$ model FEM bervariasi antar individu lebih besar dari nilai koefisien determinasi $\left(\mathrm{R}^{2}\right)$ model FEM bervariasi antar waktu dan nilai error dari FEM bervariasi antar individu sebesar 3536,74 lebih kecil dari model FEM bervariasi antar waktu sebesar 22681,91, sehingga model FEM yang lebih tepat digunakan yaitu model FEM bervariasi antar individu.

C. REM

Berikut model REM pada PDRB Jawa Timur.

$\hat{Y}_{i t}=5518,412+15,955 X_{1}-1,634 X_{2}+0,000794 X_{3}+15,221 X_{4}-1,067 X_{5}$

Nilai koefisien determinasi pada model REM sebesar 0,7238 artinya model mampu menjelaskan variasi PDRB di Jawa Timur sebesar 72,38\%, sedangkan 27,62\% lainnya dijelaskan oleh variabel lain yang belum masuk dalam model.

\section{Pemilihan Model Terbaik}

\section{A. Uji Chow}

Berikut pengujian chow pada PDRB dan faktor-faktor yang mempengaruhinya. Hipotesis:

$\mathrm{H}_{0}: \alpha_{1}=\alpha_{2}=\ldots=\alpha_{n}=0$

$\mathrm{H}_{1}$ : minimal ada satu $\alpha_{i} \neq 0$ yang berbeda

Taraf signifikan $\alpha$ sebesar 0,05 maka didapatkan daerah kritis jika tolak $\mathrm{H}_{\mathrm{o}}$ jika $\mathrm{F}_{\text {hitung }}>\mathrm{F}_{\alpha(\mathrm{n}-1, \mathrm{n} \mathrm{nT}-\mathrm{n}-\mathrm{K})}$ atau $P_{\text {value }}<\alpha$ didapatkan hasil uji chow pada Tabel 3.

Tabel 3. Uji Chow

\begin{tabular}{ccc}
\hline $\mathrm{F}_{\text {hitung }}$ & $\mathrm{F}_{0,05(37,109)}$ & $P_{\text {value }}$ \\
\hline 156,474 & 1,520 & 0,000 \\
\hline
\end{tabular}

Tabel 3 diperoleh nilai $\mathrm{F}_{\text {hitung }}$ sebesar 156,474 lebih besar daripada $\mathrm{F}_{0,05(37,109)}$ sebesar 1,520 dan $P_{\text {value }}$ sebesar 0,000 lebih kecil dari $\alpha$ sebesar 0,05 maka diputuskan tolak $\mathrm{H}_{0}$ sehingga model FEM lebih sesuai dibandingkan model CEM.

\section{B. Uji Hausman}

Berikut adalah pengujian hausman pada PDRB dan faktor-faktor yang mempengaruhinya.

Hipotesis:

$\mathrm{H}_{0}: \operatorname{corr}\left(\mathrm{X}_{\mathrm{it}}, \mathrm{e}_{\mathrm{it}}\right)=0$

$\mathrm{H}_{1}: \operatorname{corr}\left(\mathrm{X}_{\mathrm{it}}, \mathrm{e}_{\mathrm{it}}\right) \neq 0$

Taraf signifikan $\alpha$ sebesar 0,05 maka didapatkan daerah kritis jika tolak $\mathrm{H}_{\mathrm{o}}$ jika $W>\chi_{\alpha ; k}^{2}$ atau $P_{\text {value }}<\alpha$ didapatkan hasil uji hausman pada Tabel 4. 
Tabel 4. Uji Hausman

\begin{tabular}{ccc}
\hline$W$ & $\chi_{0,05,5}^{2}$ & $P_{\text {value }}$ \\
\hline 10,794 & 11,07 & 0,056 \\
\hline
\end{tabular}

Tabel 4 diperoleh nilai $W$ sebesar 10,794 lebih kecil daripada $\chi_{0,05,5}^{2}$ sebesar 11,07 dan Pvalue sebesar 0,056 lebih besar dari sebesar 0,05 maka diputuskan gagal tolak H0 sehingga model REM lebih sesuai dibandingkan model FEM.

\section{Uji Lagrange Multiplier (LM)}

Berikut adalah pengujian LM pada PDRB dan faktor-faktor yang mempengaruhinya.

Hipotesis:

$\mathrm{H}_{0}: \sigma_{\mathrm{i}}^{2}=0$

$\mathrm{H}_{1}: \sigma_{\mathrm{i}}^{2} \neq 0$

Taraf signifikan $\alpha$ sebesar 0,05 maka didapatkan daerah kritis jika tolak $\mathrm{H}_{\mathrm{o}}$ jika $\mathrm{LM}>\chi_{\alpha, k}^{2}$ atau $P_{\text {value }}<\alpha$ didapatkan hasil uji Lagrange Multiplier pada Tabel 5.

Tabel 5. Uji Lagrange Multiplier

\begin{tabular}{ccc}
\hline LM & $\chi_{0,05,5}^{2}$ & $P_{\text {value }}$ \\
\hline 215,9127 & 11,07 & 0,000 \\
\hline
\end{tabular}

Tabel 5 diperoleh nilai LM sebesar 215,9127 lebih besar daripada sebesar 11,07 dan Pvalue sebesar 0,000 lebih kecil dari $\chi_{0,05,5}^{2}$ sebesar 0,05 maka diputuskan tolak H0 sehingga model REM lebih sesuai dibandingkan model CEM.

\section{Pengujian Signifikansi Parameter}

Pengujian serentak dan pengujian parsial yang dijelaskan sebagai berikut.

\section{A. Pengujian Serentak}

Hipotesis :

$\mathrm{H}_{\mathrm{o}}: \beta_{1}=\beta_{2}=\beta_{3}=\beta_{4}=\beta_{5}=0$

$\mathrm{H}_{1}$ : Minimal terdapat satu $\beta_{k} \neq 0$

Taraf signifikan $\alpha$ sebesar 0,05 maka didapatkan daerah kritis jika tolak $\mathrm{H}_{\mathrm{o}}$ jika $\mathrm{F}_{\text {hitung }}>F \alpha,(K, \mathrm{nT}-K-1)$ atau $P_{\text {value }}<\alpha$ didapatkan hasil dari uji serentak pada Tabel 6.

Tabel 6. Uji Serentak

\begin{tabular}{ccc}
\hline $\mathrm{F}_{\text {hitung }}$ & $\mathrm{F}_{0,05(5,146)}$ & $P_{\text {value }}$ \\
\hline 76,536 & 2,276 & 0,000 \\
\hline
\end{tabular}

Tabel 6 diperoleh nilai $\mathrm{F}_{\text {hitung }}$ sebesar 76,536 lebih besar daripada $\mathrm{F}_{0,05(5,146)}$ sebesar 2,276 dan $P_{\text {value }}$ sebesar 0,000 lebih kecil dari $\alpha$ sebesar 0,05 maka diputuskan tolak $\mathrm{H}_{0}$ sehingga minimal terdapat satu variabel prediktor berpengaruh signifikan terhadap PDRB Jawa Timur.

\section{B. Pengujian Parsial}

Hipotesis:

$\mathrm{H}_{\mathrm{o}}: \beta_{k}=0$

$\mathrm{H}_{1}: \beta_{k} \neq 0$

Taraf signifikan $\alpha$ sebesar 0,05 maka didapatkan daerah kritis tolak $\mathrm{H}_{\mathrm{o}}$ jika $\left|\mathrm{t}_{\text {hitung }}\right|>\mathrm{t}_{\alpha / 2(\mathrm{nT}-\mathrm{K}-1)}$ atau $P_{\text {value }}<\alpha$ didapatkan hasil dari uji parsial pada Tabel 7.

Tabel 7 menunjukkan bahwa yang berpengaruh signifikan terhadap PDRB (Y) yaitu infrastruktur kesehatan $\left(\mathrm{X}_{1}\right)$, infrastruktur air $\left(\mathrm{X}_{3}\right)$, dan infrastruktur hotel, penginapan, dan restoran $\left(\mathrm{X}_{4}\right)$. 
Tabel 7. Uji Parsial

\begin{tabular}{cccc}
\hline Variabel & $\left|\mathrm{t}_{\text {hitung }}\right|$ & $\mathrm{t}_{(0,025,146)}$ & $P_{\text {value }}$ \\
\hline Infrastruktur Kesehatan & 2,677 & & $0,0083^{*}$ \\
Infrastruktur Pendidikan & 0,203 & & 0,8389 \\
Infrastruktur Air & 15,117 & 2,265 & $0,0000^{*}$ \\
Infrastruktur Hotel, Penginapan, dan Restoran & 3,580 & & $0,0005^{*}$ \\
Infrastruktur Jalan & 0,924 & & 0,3570 \\
\hline
\end{tabular}

Keterangan: *) Signifikan pada taraf kepercayaan 95\%

\section{Pemodelan dengan Variabel yang Signifikan}

Model REM pada faktor-faktor yang mempengaruhi PDRB Jawa Timur berdasarkan kondisi infrastruktur sebagai berikut.

$$
\hat{Y}_{i t}=4481,77+14,584 X_{1}+0,000795 X_{3}+15,156 X_{4}+\mu_{i}
$$

Berdasarkan model REM diatas didapatkan nilai koefisien determinasi sebesar 0,7235 , yang artinya model menjelaskan variasi PDRB di Jawa Timur sebesar 72,35\% dan sisanya 27,65\% dijelaskan oleh variabel lain yang belum masuk dalam model. Nilai $\mu_{i}$ menunjukkan nilai error masing-masing Kabupaten/Kota di Jawa Timur yang ditunjukkan pada Tabel 8.

Tabel 8. Nilai Efek Error Masing-masing Kabupaten/Kota

\begin{tabular}{lllllc}
\hline No & Kab/Kota & Effect & No & Kab/Kota & Effect \\
\hline 1 & Pacitan & $-11289,47$ & 20 & Magetan & $-20314,09$ \\
2 & Ponorogo & $-14346,95$ & 21 & Ngawi & $-18703,89$ \\
3 & Trenggalek & $-9862,599$ & 22 & Bojonegoro & 23330,56 \\
4 & Tulungagung & $-4295,333$ & 23 & Tuban & 3758,344 \\
5 & Blitar & $-7415,123$ & 24 & Lamongan & $-15021,5$ \\
6 & Kediri & $-10447,08$ & 25 & Gresik & 45890,97 \\
7 & Malang & $-27515,1$ & 26 & Bangkalan & $-10319,25$ \\
8 & Lumajang & $-11587,3$ & 27 & Sampang & $-11240,2$ \\
9 & Jember & $-5478,923$ & 28 & Pamekasan & $-14808,66$ \\
10 & Banyuwangi & $-2261,452$ & 29 & Sumenep & $-10261,09$ \\
11 & Bondowoso & $-11541,52$ & 30 & Kota Kediri & 69256,75 \\
12 & Situbondo & $-13140,16$ & 31 & Kota Blitar & $-4254,621$ \\
13 & Probolinggo & $-7779,323$ & 32 & Kota Malang & $-5280,424$ \\
14 & Pasuruan & 45415,80 & 33 & Kota Probolinggo & $-5040,979$ \\
15 & Sidoarjo & 67236,91 & 34 & Kota Pasuruan & $-8148,751$ \\
16 & Mojokerto & 22852,85 & 35 & Kota Mojokerto & $-3297,609$ \\
17 & Jombang & $-8837,77$ & 36 & Kota_Madiun & $-7518,819$ \\
18 & Nganjuk & $-14114,89$ & 37 & Kota Batu & $-15106,73$ \\
19 & Madiun & $-12694,08$ & 38 & Kota Surabaya & 44181,51 \\
\hline
\end{tabular}

Tabel 8 menunjukkan nilai efek error untuk mengetahui seberapa besar perbedaan komponen kesalahan random pada setiap Kabupaten/Kota di Jawa Timur terhadap nilai intersep semua Kabupaten/Kota di Jawa Timur. Nilai intersep (c) menunjukkan rata-rata dari komponen kesalahan random yaitu sebesar 4481,77. Nilai koefisien efek acak Kabupaten Pacitan, yaitu -11289,47 yang menunjukkan seberapa jauh error acak komponen Kabupaten Pacitan berbeda dari intersepnya. Demikian pula untuk Kabupaten/Kota yang lain.

\section{Pengujian Asumsi Residual IIDN}

Tujuan dari pengujian asumsi residual IIDN (Identik, Indenpenden, dan berdistribusi Normal) untuk mengetahui penyebaran error dari faktor-faktor yang mempengaruhi PDRB Jawa Timur di Jawa Timur dengan variabel prediktor signifikan berdasarkan pada model yang diestimasi menggunakan Random Effect Model melalui satu asumsi yaitu uji asumsi berdistribusi normal, sedangkan uji asumsi identik dan uji asumsi independen tidak perlu dilakukan karena metode GLS menghasilkan estimator untuk memenuhi sifat Best Linier Unbiased Estimation (BLUE) dalan menangani pelanggaran asumsi heteroskedastisitas dan autokorelasi (Greene, 2006). 


\section{Pengujian Asumsi Residual Berdistribusi Normal}

Berikut uji asumsi residual berdistribusi normal menggunakan uji Jarque Bera.

Hipotesis:

$\mathrm{H}_{0}$ : residual PDRB Jawa Timur berdistribusi normal

$\mathrm{H}_{1}$ : residual PDRB Jawa Timur tidak berdistribusi normal

Ditetapkan taraf signifikan $\alpha$ sebesar 0,05 maka didapatkan daerah krisis tolak $\mathrm{H}_{0}$ jika $J B$ lebih besar dari $\chi_{\alpha ; 2}^{2}$ atau $P_{\text {value }}>\alpha$ didapatkan st pada Tabel 9.

Tabel 9. Uji Asumsi Berdistribusi Normal

\begin{tabular}{ccc}
\hline$J B$ & $\chi_{0,05 ; 2}^{2}$ & $P_{\text {value }}$ \\
\hline 112,68 & 5,991 & 0,000 \\
\hline
\end{tabular}

Tabel 9 diperoleh nilai $J B$ sebesar 112,68 lebih besar dari nilai $\chi_{0,05 ; 2}^{2}$ sebesar 5,991 dan diperkuat dengan nilai $P_{\text {value }}$ sebesar 0,000 lebih kecil dari $\alpha$ sebesar 0,05 maka diputuskan untuk tolak $\mathrm{H}_{0}$ disimpulkan residual tidak memenuhi asumsi berdistribusi normal.

\section{KESIMPULAN}

Hasil dari analisis yang telah diperoleh dapat disimpulkan bahwa kota di Jawa Timur yang unggul di semua infrastruktur adalah Kota Surabaya dan dapat dilihat dari nilai PDRB tertinggi pada tahun 2016 - 2019 berada di Kota Surabaya dibandingkan Kabupaten/Kota lain di Jawa Timur. Model terbaik yang terpilih adalah REM dengan variabel infrastruktur kesehatan (X1), infrastruktur air (X3), dan infrastruktur hotel, penginapan, dan restoran (X4) berpengaruh signifikan terhadap PDRB Jawa Timur dengan koefisien determinasi sebesar $72,35 \%$. Diperoleh model REM sebagai berikut.

$$
\hat{Y}_{i t}=4481,77+14,584 X_{1}+0,000795 X_{3}+15,156 X_{4}+\mu_{i}
$$

Model diatas menunjukkan bahwa ketika infrastruktur kesehatan (X1) bertambah 1 unit maka nilai PDRB (Y) akan bertambah sebesar 14,584 miliar rupiah dengan syarat infrastruktur air (X3) dan infrastruktur hotel, penginapan, dan restoran (X4) konstan. Ketika infrastruktur air (X3) bertambah $1 \mathrm{~m} 3$ maka nilai PDRB (Y) akan bertambah sebesar 0,000795 miliar rupiah dengan syarat infrastruktur kesehatan (X1) dan infrastruktur hotel, penginapan, dan restoran (X4) konstan. Ketika infrastruktur hotel, penginapan, dan restoran (X4) bertambah 1 unit maka nilai PDRB (Y) akan bertambah sebesar 15,156 miliar rupiah dengan syarat infrastruktur kesehatan (X1) dan infrastruktur air (X3) konstan.

\section{DAFTAR PUSTAKA}

Atmaja, H., \& Mahalli, K. (2015). Pengaruh Peningkatan Infrastruktur Terhadap Pertumbuhan Ekonomi Di Kota Sibolga. Jurnal Ekonomi Dan Keuangan, 3(4), 14847.

BPS Provinsi Jawa Timur. (2020). Produk Domestik Regional Bruto Kabupaten/Kota di Provinsi Jawa Timur Menurut Lapangan Usaha 2015-2019 (Vol. 53, Issue 9, pp. 1689-1699). Badan Pusat Statistik Provinsi Jawa Timur.

Greene, W. . (2006). Econometric Analysis, Sixth Edition. Pearson Education.

Greene, W. H. (2003). Econometric Analysis. Pearson Education, Inc.

Gujarati, D. N. (2004). Basic Econometrics (4th ed.). McGraw-Hill.

Hsiao, C. (2003). Analysis of Panel Data, second edition. In Analysis of Panel Data, Second Edition. Cambridge University Press. https://doi.org/10.1017/CBO9780511754203

Kodoatie, R. . (2003). Manajemen dan Rekayasa Infrastruktur. Pustaka Belajar.

Rokhmat, A., Sasana, H., SBM, N., \& Yusuf, E. (2020). Analisis Pengaruh Pembangunan Infrastruktur Pelayanan Dasar, Jalan Provinsi, Air Bersih, Hotel, Penginapan dan Restoran Terhadap Produk Regional Bruto. Jurnal Riset Ekonomi Dan Bisnis, 13(2), 100-110.

Setiawan, \& Kusrini, D. . (2010). Ekonometrika. Penerbit Andi.

Widarjono, A. (2013). Ekonometrika Pengantar dan Aplikasinya Disertai Panduan Eviews (edisi 4). UPP STIM YKPN. 